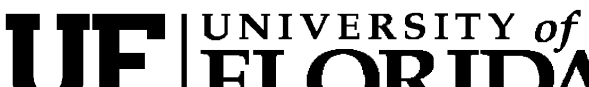 FLORIDA \\ IFAS Extension
}

\section{Whitefly-Transmitted Cucurbit Leaf Crumple Virus in Florida ${ }^{1}$}

\section{S. E. Webb, F. Akad, T. W. Nyoike, O. E. Liburd, and J. E. Polston²}

In November 2006, Cucurbit leaf crumple virus (CuLCrV), a virus new to Florida, was found in squash (Cucurbita pepo L.) fields in north central and northeast Florida. Leaves of yellow straightneck squash and zucchini were thickened and distorted, as well as curled and crumpled. The symptoms on infected yellow straightneck squash (Figure 1) were slightly different from those on zucchini (Figures 2 and 3). The leaves of yellow straightneck squash plants were rounded on the edges while leaves of zucchini plants were not. Zucchini fruit did not show obvious symptoms, but the fruit from infected yellow straightneck squash were streaked with green, making them unmarketable (Figure 4). Feeding by whitefly nymphs causes silvering of leaves of squash and blanching of yellow-fruited squash and yellow blotchiness of green-fruited squashes. The leaf silvering shown in Figures 2 and 3 is distinct from cucurbit leaf crumple disease and should be not be confused with it.

Samples collected from symptomatic plants failed to react in ELISA with antibodies to all cucurbit-infecting viruses known to be present in Florida. The samples also tested negative for the

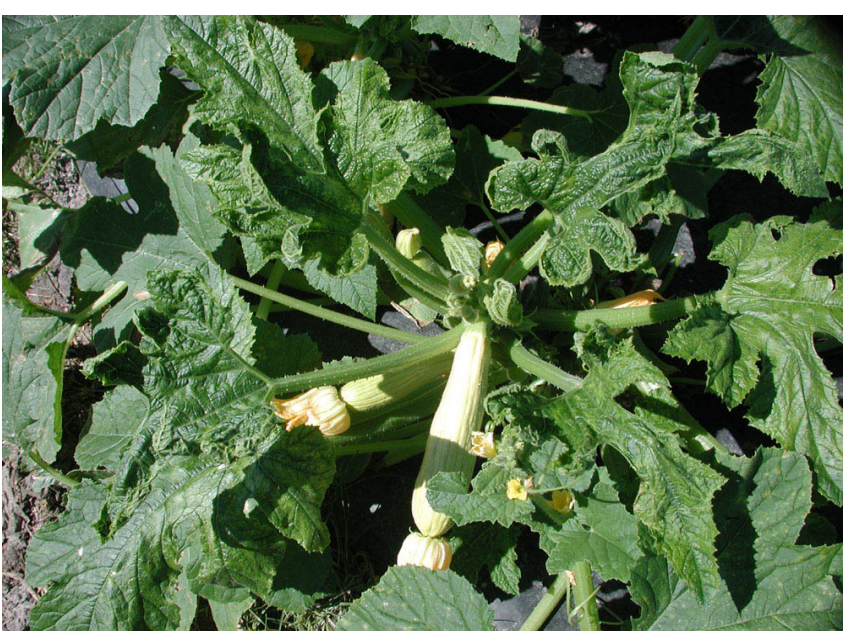

Figure 1. Yellow straightneck squash infected with Cucurbit leaf crumple virus. Credits: Chad Hutchinson, University of Florida

whitefly-transmitted potyvirus Squash vein yellowing virus (Adkins et al., 2007), but did test positive in PCR assays for Begomovirus. PCR followed by sequence analysis and whitefly transmission tests revealed that the plants were infected with Cucurbit leaf crumple virus.

Cucurbit leaf crumple virus is a begomovirus reported from the western United States (Arizona,

1. This document is Fact Sheet ENY-477 (IN716), a series of the Entomology and Nematology Department, Florida Cooperative Extension Service, Institute of Food and Agricultural Sciences, University of Florida. Publication date: March 2007. Please visit the EDIS Website at http://edis.ifas.ufl.edu.

2. S. E. Webb, associate professor, O. E. Liburd, associate professor, and T. W. Nyoike, graduate student, Entomology and Nematology Department, F. Akad, postdoctoral research associate, and J. E. Polston, professor, Plant Pathology Department, Institute of Food and Agricultural Sciences, University of Florida, Gainesville, FL.

The Institute of Food and Agricultural Sciences (IFAS) is an Equal Opportunity Institution authorized to provide research, educational information and other services only to individuals and institutions that function with non-discrimination with respect to race, creed, color, religion, age, disability, sex, sexual orientation, marital status, national origin, political opinions or affiliations. U.S. Department of Agriculture, Cooperative Extension Service, University of Florida, IFAS, Florida A. \& M. University Cooperative Extension Program, and Boards of County Commissioners Cooperating. Larry Arrington, Dean 


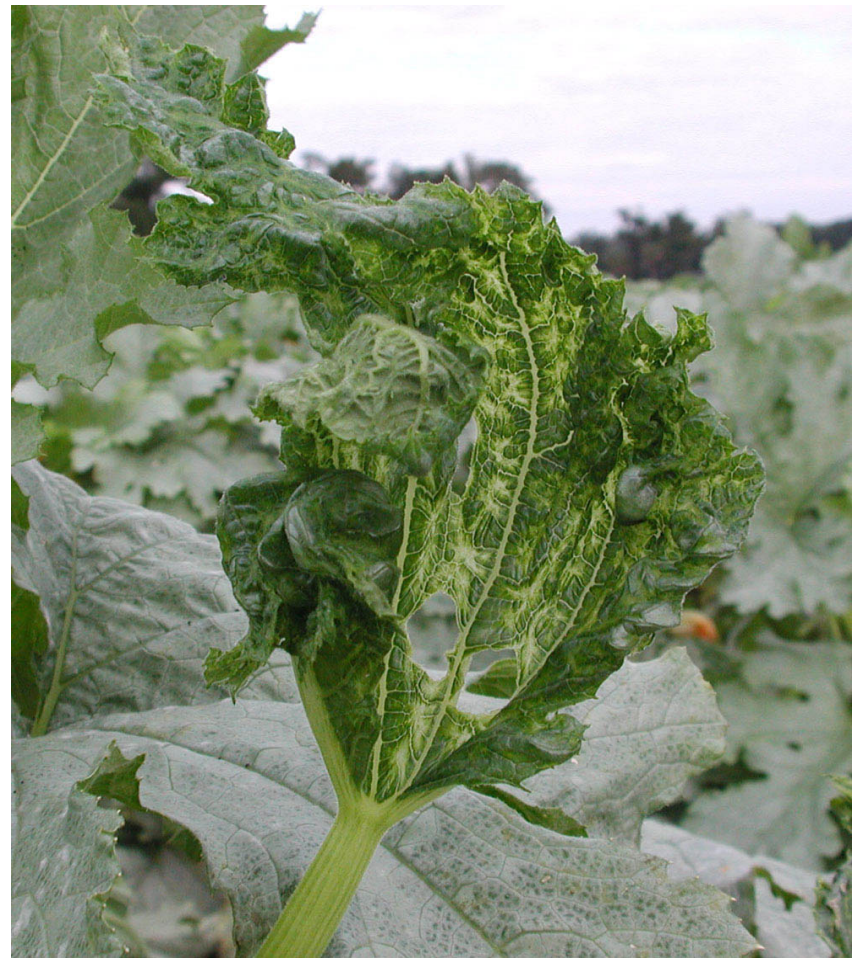

Figure 2. Zucchini squash infected with Cucurbit leaf crumple virus. Note silverleaf symptoms in background due to feeding of immature whiteflies. Credits: S. E. Webb, University of Florida

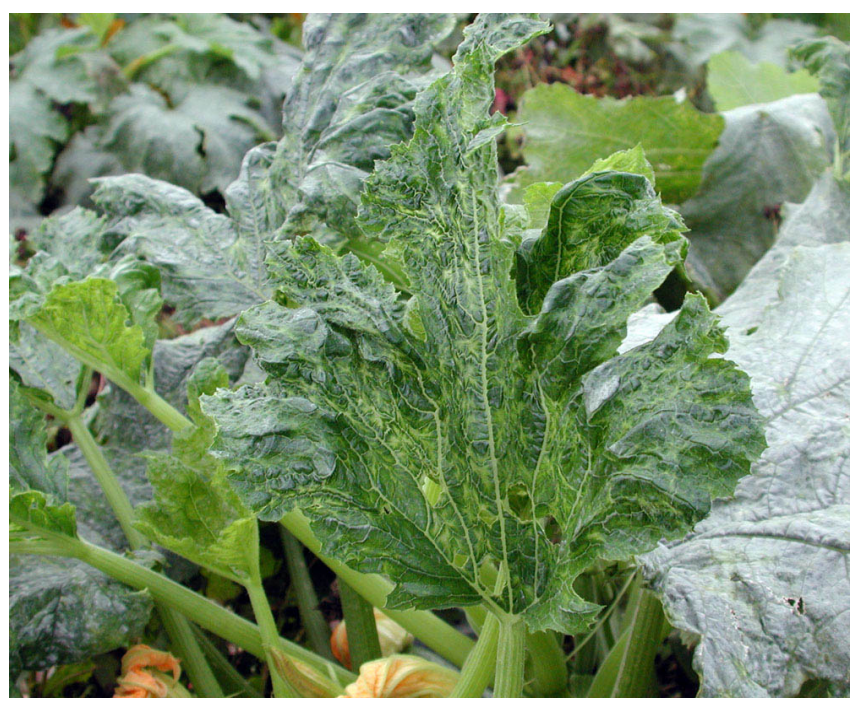

Figure 3. Zucchini squash infected with Cucurbit leaf crumple virus. Note silverleaf symptoms in background due to feeding of immature whiteflies. Credits: S. E. Webb, University of Florida

Texas and California) and northern Mexico (Brown et al., 2000, Brown et al., 2002) (Cucurbit leaf crumple virus has been known in some locations as Cucurbit leaf curl virus). Cucurbit leaf crumple virus is able to infect most cucurbits including cucumber, muskmelon, squash, pumpkin, and watermelon, and

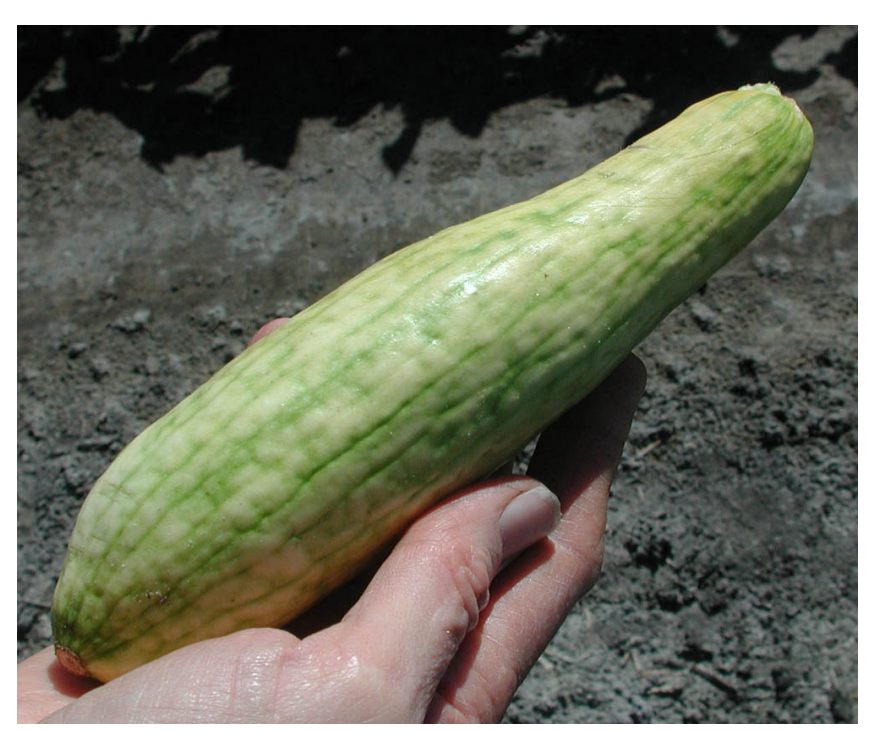

Figure 4. Yellow straightneck squash fruit infected with Cucurbit leaf crumple virus. Credits: Chad Hutchinson, University of Florida

has been reported to infect bean. Honeydew, Crenshaw, and casaba melons appear to be immune (Natwick, 2003). As with other begomoviruses, this virus is transmitted in a persistent manner by various biotypes of the whitefly, Bemisia tabaci (Genn.), including the silverleaf whitefly (B. tabaci biotype B $=B$. argentifolii Bellows \& Perring). The adult whitefly must feed for a minimum of 30 minutes on the infected plant and can only transmit the virus after a delay of 6-8 hours. Once the whitefly is able to transmit the virus, it can continue to do so for days. The virus cannot be transmitted mechanically and is unlikely to be transmitted through seed.

Whitefly populations were exceptionally high in fall 2006 in north central and northeast Florida, possibly because of the drought conditions during the summer. Heavy summer rains can reduce populations under normal conditions, but whiteflies may also have become concentrated on irrigated crop plants when weed hosts wilted. These high populations may be responsible for the high incidences of Cucurbit leaf crumple virus-infected plants in both locations.

Management of this new virus will not be much different than management of other begomoviruses in vegetable crops such as Tomato yellow leaf curl virus in tomato (Schuster and Polston, 1999, Momol et al., 2001). Virus- and whitefly-free transplants should be used, and transplants produced in states where this virus is known to be a problem (Texas, Arizona, 
California) should not be planted in Florida. Where whiteflies are a problem, a soil-applied neonicotinoid insecticide such as imidacloprid (Admire ${ }^{\circledR}$ ), thiamethoxam (Platinum $^{\circledR}$ ), or dinotefuran $\left(\right.$ Venom $\left.^{\circledR}\right)$ should be used at planting. If a foliar application of dinotefuran is used instead of a soil application, it is best to apply it in the first 30 days of the crop, before flowering. In addition to protecting bees, it also will help limit the exposure of the whitefly population to neonicotinoids during the latter part of the crop cycle. The crop should be monitored regularly for the presence of adult whiteflies. An application of pymetrozine $\left(\right.$ Fulfill $\left.^{\circledR}\right)$ will reduce the number of adults and nymphs and can help slow virus spread into and within the crop. Other materials that can be used to reduce adult populations include endosulfan or a combination of bifenthrin and endosulfan. A new product, spiromesifen $\left(\right.$ Oberon $\left.^{\circledR}\right)$, is effective against immature stages of the whitefly as is buprofezin (Courier ${ }^{\circledR}$ ), an insect growth regulator. Although spiromesifen and buprofezin affect only reproduction and survival of immatures, they can help reduce secondary spread within and between fields by slowing the increase of the whitefly population. Because of concerns about insecticide resistance in whiteflies, it is critically important to observe the restrictions on the number of applications, to rotate insecticide applications among chemicals in different classes, and never follow a soil application of any neonicotinoid with a foliar application of another neonicotinoid. Further information on management of both begomoviruses and resistance to neonicotinoids can be found on the Whitefly MoA poster at the IRAC (Insecticide Resistance Action Committee) Website http://www.irac-online.org

In addition to starting with virus- and whitefly-free transplants, other effective cultural controls include avoiding planting next to older, whitefly-infested crops (virus and whitefly hosts such as beans and other cucurbits, but also whitefly hosts such as cabbage, collards, peanuts, tomato, cotton, and soybeans). Use UV-reflective mulches, which repel migrating whiteflies in the first few weeks of the crop (until canopy closure), thus delaying the introduction of virus. These mulches also repel aphids and will give additional benefits by reducing early spread of aphid-transmitted viruses. Remove weeds from fields, as they can be hosts for whiteflies, and can interfere with thorough coverage with insecticides applied for whitefly control.

The distribution of Cucurbit leaf crumple virus in Florida is not yet known. Samples of plants suspected to be infected with this virus can be submitted to County Extension Offices for testing by one of the UF/IFAS Plant Disease Clinics.

\section{References Cited}

Adkins, S., S. E. Webb, D. Achor, P. D. Roberts, and C. A. Baker. 2007. Identification and characterization of a novel whitefly-transmitted member of the family Potyviridae isolated from cucurbits in Florida. Phytopathology 97:145-154.

Brown, J. K., A. M. Idris, C. Alteri and D. C. Stenger. 2002. Emergence of a new cucurbitinfecting begomovirus species capable of forming viable reassortants with related viruses in the Squash leaf curl virus cluster. Phytopathology 92: 734-742.

Brown, J. K., A. M. Idris, M. W. Olsen, M. E. Miller, T. Isakeit, and J. Anciso. 2000. Cucurbit leaf curl virus, a new whitefly transmitted geminivirus in Arizona, Texas, and Mexico. Plant Dis. 84:809.

Momol, T., S. Olson, J. Funderburk, and R. Sprenkel. 2001. Management of Tomato yellow leaf curl virus (TYLCV) in tomato in north Florida. Fact Sheet PP-184, 2 pp., University of Florida, IFAS, Gainesville.

Natwick, E. T. 2003. New virus disease in melons and squash is identified and described. http://ucanr.org/delivers/impactview.cfm? impactnum $=140$

Schuster, D. J. and J. E. Polston. 1999. Whitefly Management Guide: Tomato yellow leaf curl virus. Supplement in Citrus and Vegetable Magazine/The Grower, Summer 1999, pp. A6-A7. 